\title{
POTENTIAL OF GRASSES AND RHIZOSPHERE BACTERIA FOR BIOREMEDIATION OF DIESEL-CONTAMINATED SOILS
}

\author{
Melissa Paola Mezzari(1), Daniela Mara Hoffmann Zimermann ${ }^{(2)}$, \\ Henry Xavier Corseuil ${ }^{(3)}$ \& Alexandre Verzani Nogueira ${ }^{(4)}$
}

\begin{abstract}
SUMMARY
The techniques available for the remediation of environmental accidents involving petroleum hydrocarbons are generally high-cost solutions. A cheaper, practical and ecologically relevant alternative is the association of plants with microorganisms that contribute to the degradation and removal of hydrocarbons from the soil. The growth of three tropical grass species (Brachiaria brizantha, Brachiaria decumbens and Paspalum notatum) and the survival of root-associated bacterial communities was evaluated at different diesel oil concentrations. Seeds of three grass species were germinated in greenhouse and at different doses of diesel $\left(0,2.5,5\right.$ and $10 \mathrm{~g} \mathrm{~kg}^{-1}$ soil). Plants were grown for 10 weeks with periodic assessment of germination, growth (fresh and dry weight), height, and number of bacteria in the soil (pots with or without plants). Growth and biomass of $B$. decumbens and $P$. notatum declined significantly when planted in diesel-oil contaminated soils. The presence of diesel fuel did not affect the growth of $B$. brizantha, which was highly tolerant to this pollutant. Bacterial growth was significant $(p<0.05)$ and the increase was directly proportional to the diesel dose. Bacteria growth in diesel-contaminated soils was stimulated up to 5-fold by the presence of grasses, demonstrating the positive interactions between rhizosphere and hydrocarbon-degrading bacteria in the remediation of diesel-contaminated soils.
\end{abstract}

Index terms: diesel fuel, microbial count, plant growth.

\footnotetext{
(1) Received for publication in January 24, 2010 and approved in August 18, 2011.

(2) Postdoctoral researcher at the Environmental Engineering Department, CAPES-PNPD Scholarship. Federal University of Santa Catarina - UFSC. Campus Universitário, Bairro Trindade, Caixa postal 476, CEP 88040-970 Florianópolis (SC). E-mail: mmezzari@gmail.com

${ }^{(3)}$ Master student, Graduate Program in Environmental Engineering, Federal University of Santa Catarina - UFSC. E-mail: danielamhz@gmail.com

(4) Professor at the Department of Sanitary and Environmental Engineering, UFSC. E-mail: corseuil@ens.ufsc.br

(5) Professor at the Department of Microbiology, Immunology and Parasitology, UFSC. E-mail: alexandre@ccb.ufsc.b
} 


\title{
RESUMO: POTENCIAL DE GRAMÍNEAS E DE BACTÉRIAS DA RIZOSFERA NA REMEDIAÇÃO DE SOLOS CONTAMINADOS COM ÓLEO DIESEL
}

\begin{abstract}
Os processos de remediação de acidentes ambientais causados por hidrocarbonetos de petróleo geralmente envolvem soluções de alto custo. Uma solução alternativa, de baixo custo e com relevância prática e ecológica é a associação de plantas e microrganismos, os quais contribuem para a degradação e remoção de hidrocarbonetos no solo. $O$ crescimento de três espécies de gramineas (Brachiaria brizantha, Brachiaria decumbens $e$ Paspalum notatum) e a sobrevivência de comunidades bacterianas associadas à zona de raizes foram avaliados sob diferentes concentrações de óleo diesel. Sementes das três espécies de gramíneas foram germinadas em casa de vegetação e em diferentes doses de diesel: 0; 2, 5; 5; $10 \mathrm{~g} \mathrm{~kg}^{-1}$ solo. As plantas foram cultivadas por 10 semanas, com avaliação periódica de germinação, crescimento (peso do material fresco e seco), altura e número de bactérias no solo (vasos com plantas ou sem plantas). Houve diminuição significativa do crescimento e da biomassa de $\mathrm{B}$. decumbens $e \mathrm{P}$. notatum quando cultivadas em solos contaminados por óleo diesel. A presença do óleo não comprometeu o crescimento de B. brizantha, a qual apresentou elevada tolerância ao poluente. O crescimento de bactérias foi significativo $(p<0,05)$, sendo o aumento diretamente proporcional às doses de diesel. A presença das gramíneas em solos com diesel propiciou o crescimento de bactérias no solo em até cinco vezes, evidenciando as interações positivas entre a rizosfera e as bactérias degradadoras de hidrocarbonetos na remediação de solos contaminados com diesel.
\end{abstract}

Termos de indexação: óleo diesel, contagem bacteriana, crescimento da planta.

\section{INTRODUCTION}

The contamination of soils with fossil fuels can accidentally occur during its transport, storage or use. Diesel-contaminated soils can pose hazardous risks to public health by direct skin contact or by inhalation of toxic vapors (Pohl et al., 1997; Chilcott, 2011). The presence of diesel can also contribute to the deterioration of soil quality and the contamination of water supplies by hydrocarbons that end up in surface waters or groundwater sources.

The remediation techniques used for soil surfaces contaminated with diesel fuel are typically based on the removal of the contaminated zone through soil excavation and off-site treatments, which include landfarming or disposal in industrial landfills (EPA, 1994). Though often used, these remediation strategies may entail site disturbance and high costs associated with soil excavation, transportation and landfilling. Moreover, soil excavation may not completely remove the entire source of pollution, leaving residual hydrocarbon contamination that often exceeds regulatory limits, over extensive areas.

Phytoremediation can alternatively be applicable as a remediation technique, using plants for uptake and removal of organic and inorganic compounds from contaminated soils, sediments and groundwater (Schnoor, 1995). It is an inexpensive and efficient remediation strategy that can be used to remove diesel hydrocarbons from surface soils. During the past 15 years, many laboratory studies and on-site experiments have confirmed the efficiency of removing hydrocarbons through phytoremediation (Cunningham et al., 1996; Burken \& Schnoor, 1999; Tesar et al., 2002; Kim et al., 2006).

Efficacy of phytoremediation strongly depends on a large and deep penetrating root system and a high transpiration rate (Komives \& Gullner, 2006). When the pollutant is assimilated and translocated within plant tissues, metabolic transformation processes occur that are mediated by a great variety of enzymes for several types of substrates (Sanderman, 1994; Coleman et al., 1997; Mezzari et al., 2004, 2005). The plant metabolic transformation process depends directly on the solubility and bioavailability of the pollutant, to make phytoremediation a feasible process. Physicochemical and structural properties determine the uptake of organic chemicals by plant roots from the soil. Moderately hydrophobic organic compounds (characterized with and the octanol-water partition coefficient, $\log \mathrm{K}_{\mathrm{ow}}$, with values between 1 and 3 ) available in diesel fuel are readily taken up by plant roots. Hydrophilic (log $\mathrm{K}_{\mathrm{ow}}<1$ ) and strongly hydrophobic compounds $\left(\log \mathrm{K}_{\mathrm{ow}}>3\right)$ are unavailable for uptake because of their strong bonding to soil particles or to plant roots (Kamath et al., 2004). Diesel fuel is mainly composed of polycyclic aromatic hydrocarbons (PAH), which are highly hydrophobic, and of hydrophilic monoaromatics, such as BTEX (benzene, toluene, ethyl benzene, and xylene) (Schnoor, 1996).

The microbial population present in the rhizosphere or near the root zone can degrade the pollutant or make it more bioavailable, challenging the plant 
tolerance when exposed to it challengin(Pichtel \& Liskanen, 2001; Merkl et al., 2005). Microbial contribution is essential for phytoremediation of diesel and many organic hydrophobic compounds, since the removal of these pollutants from the environment becomes more feasible through the metabolic transformation processes of plant-microbe interaction (Chaudhry et al., 2005). Rhizoremediation is the mechanism where microbial populations of mostly the root zone contribute to the overall breakdown and removal of pollutants from the environment (Anderson et al., 1993; Kuiper et al., 2004). The plant rhizosphere is usually composed of a diverse range of microbial populations, rather than of a single strain (Chaudhry et al., 2005; Leigh, 2006). The composition of the microbial population in the rhizosphere depends on the composition of root exudates, plant species, root type, plant age, soil type, soil history, environmental factors, and the presence of pollutants (Anderson et al., 1993; Kuiper et al., 2004; Chaudhry et al., 2005; Da Silva et al., 2006).

Some studies have identified grasses as potential phytoremediation plants for diesel-contaminated sites (Pichtel \& Liskanen, 2001; Siddiqui \& Adams, 2002; Kim et al., 2006). Thus, the assessment of native site-specific grasses is recommended for a better understanding of the phytoremediation potential for each particular, site-specific situation. This study evaluated the ability of grasses (Brachiaria brizantha, Brachiaria decumbens and Paspalum notatum) to grow in soils exposed to different diesel concentrations. Total soil bacteria were also quantified to elucidate the effects of plant-promoted bacterial stimulation on diesel biodegradation.

\section{MATERIALS AND METHODS}

This study was conducted in a greenhouse of the Federal University of Santa Catarina (Florianópolis, Brazil). Soil collected from a depth of $15 \mathrm{~cm}$ was taken from an experimental field (Corseuil et al., 2011) and used for grass germination. Soil was characterized as a dystrophic, sandy, undeveloped hydromorphic Quartzarenic Neosol, with transitional horizons from $\mathrm{A}$ to $\mathrm{C}$. The groundwater has high water table fluctuations with hydraulic conductivity of $10^{-2}$ to $10^{-4} \mathrm{~m} \mathrm{~s}^{-1}$ (mainly silts and fine sands) with an effective porosity of 18 to $20 \%$. Chemical and physical analysis were performed for soil characterization at a subcontracted laboratory (Companhia Integrada de Desenvolvimento Agrícola de Santa Catarina CIDASC) (Table 1).

The collected soil was dried and sieved (mesh $2 \mathrm{~mm}$ ) prior to $\mathrm{pH}$ adjustment based on the SMP buffer index (Table 1). Calcium carbonate and magnesium oxide were added to the soil at a concentration of 1:3(v/v), respectively (Braga, 1991). Soil moisture was increased to $75 \%$ of field capacity. It took 15 days to
Table 1. Chemical and physical characteristics of the soil used in the experiment

\begin{tabular}{|c|c|c|}
\hline Characteristic & Value & $\operatorname{Ref}^{(1)}$ \\
\hline Soil layer $(\mathrm{cm})$ & $0-50$ & \\
\hline Clay $\left(\mathrm{g} \mathrm{kg}^{-1}\right)$ & 120 & class 4 \\
\hline $\mathrm{pH}$ & 5.2 & low \\
\hline SMP buffer index & 5.0 & \\
\hline Calcium $\left(\mathrm{cmol}_{\mathrm{c}} \mathrm{dm}^{-3}\right)$ & 0.3 & low \\
\hline Magnesium $\left(\mathrm{cmol}_{\mathrm{c}} \mathrm{dm}^{-3}\right)$ & 0.2 & low \\
\hline Sodium $\left(\mathrm{mg} \mathrm{m}^{-3}\right)$ & 16 & \\
\hline Phosphorus $\left(\mathrm{mg} \mathrm{m}^{-3}\right)$ & 5.3 & very low \\
\hline Potassium $\left(\mathrm{mg} \mathrm{dm}^{-3}\right)$ & 26 & very low \\
\hline Aluminum $\left(\mathrm{cmol}_{\mathrm{c}} \mathrm{dm}^{-3}\right)$ & 2.0 & \\
\hline $\mathrm{H}+\mathrm{Al}\left(\mathrm{cmol}_{\mathrm{c}} \mathrm{dm}^{-3}\right)$ & 8.79 & \\
\hline $\mathrm{pH}-\mathrm{CaCl}_{2}$ & 4.2 & very high \\
\hline $\mathrm{S}$ (sum of bases) $\left(\mathrm{cmol}_{\mathrm{c}} \mathrm{dm}^{-3}\right)$ & 0.64 & low \\
\hline CEC (Cation-Exchange Capacity) $\left(\mathrm{cmol}_{\mathrm{c}} \mathrm{dm}^{-3}\right)$ & 9.43 & medium \\
\hline Organic Matter $\left(\right.$ dag kg $\left.\mathrm{kg}^{-1}\right)$ & 6.2 & high \\
\hline V (soil base saturation) (\%) & 6.77 & very low \\
\hline
\end{tabular}

(1) Interpretation according to recommendations for fertilization and liming in the states of Rio Grande do Sul and Santa Catarina, SBCS - Núcleo regional Sul / EMBRAPA - CNPT, 2004. The $\mathrm{pH}, \mathrm{CaCl}_{2}, \mathrm{~S}, \mathrm{CEC}$ and $\mathrm{V}$ determinations are described in the Technical Bulletin No. 31 - Emater/Paraná and the others were interpreted according to the manual for fertilization and liming for the states of Rio Grande do Sul and Santa Catarina (SBCS, 2004).

complete the soil neutralization process (Embrapa, 1997). Upon soil neutralization, $10 \mathrm{~mL}$ of diluted nutrient solution was added (Raij et al., 1991). Each pot received diluted nutrients at the following concentrations (in mg kg-1 soil): $300 \mathrm{P}\left(\mathrm{KH}_{2} \mathrm{PO}_{4}\right), 100$ $\mathrm{N}\left(\mathrm{NH}_{4} \mathrm{HPO}_{4}\right), 150 \mathrm{~K}\left(\mathrm{~K}_{2} \mathrm{SO}_{4}\right)$, and micronutrients (3.7 $\mathrm{Mn}$ as $\mathrm{MnCl}_{2} .4 \mathrm{H}_{2} \mathrm{O}, 1.6 \mathrm{Fe}$ as $\mathrm{FeSO}_{4} .7 \mathrm{H}_{2} \mathrm{O}, 1.4$ $\mathrm{Cu}$ as $\mathrm{CuSO}_{4} .5 \mathrm{H}_{2} \mathrm{O}, 0.2 \mathrm{Mo}$ as $\mathrm{NaMoO}_{4} \cdot 2 \mathrm{H}_{2} \mathrm{O}, 4.0 \mathrm{Zn}$ as $\mathrm{ZnSO}_{4 \cdot 7} \mathrm{H}_{2} \mathrm{O}$ and $0.8 \mathrm{~B}$ as $\mathrm{H}_{3} \mathrm{BO}_{3}$ ).

Diesel fuel was purchased at a local gas station. Liming, fertilization, and contamination procedures were performed in plastic bags containing $0.3 \mathrm{dm}^{3}$ of sieved soil to allow a thorough mix of salts, nutrients and diesel. Diesel was soil-applied at three concentrations $\left(\mathrm{V}_{\text {diesel }} / \mathrm{V}_{\text {soil }}\right)$ : 0.5, 1 and $2 \%(2.5,5$ and $10 \mathrm{~g} \mathrm{~kg}^{-1}$, respectively). Each contaminated soil was transferred to plastic pots ( $300 \mathrm{~mL}$ volume) lined with a filter paper $(40 \mu \mathrm{m})$ at the bottom to prevent soil from leaching out after watering. B. brizantha, $B$. decumbens and $P$. notatum were seeded $2 \mathrm{~mm}$ below the soil surface. Unplanted pots with the same diesel concentrations were prepared and used as negative control. The experiment was designed in a $4 \mathrm{x} 4$ factorial arrangement of treatments: three grass species $(B$. brizantha, B. decumbens, $P$. notatum) plus unplanted controls, and three diesel treatments plus an uncontaminated control. All experiments were performed in triplicates.

Pots were watered daily to maintain soil humidity close to field capacity. The experiments were conducted 
inside a greenhouse supplied with natural sunlight and at room temperature (averages between 30 and $16{ }^{\circ} \mathrm{C}$ ). Shoot development was measured once a week by recording the maximum height in relation to the soil surface. The diesel toxicity effects associated with germination rate were analyzed in the first three weeks of the experiment. The experiment lasted 10 weeks from sowing to sampling and biomass weighing. The biomass of plant shoots cut approximately $0.5 \mathrm{~cm}$ above the soil surface was measured. Root biomass was weighed after removal from the soil and washing. To measure dry weight, plant tissues were dried in a convection oven at controlled temperature (65 and $70{ }^{\circ} \mathrm{C}$ ) for $72 \mathrm{~h}$.

Soil bacteria were quantified at the end of the $4^{\text {th }}$ and $10^{\text {th }}$ (last) experimental week by counting the number of colony-forming units (CFU's). Soil samples $(10 \mathrm{~g})$ were collected from $2 \mathrm{~cm}$ below the soil surface and $2 \mathrm{~cm}$ away from the pot edge using sterile spatulas. Soil was serially diluted with $0.85 \% \mathrm{NaCl}$, and $0.1 \mathrm{~mL}$ from $10^{-4}$ and $10^{-5}$ dilutions was spread on TSA (Tryptic Soy Agar) plates, which were incubated at $25^{\circ} \mathrm{C}$ for up to $96 \mathrm{~h}$ (Banks et al., 2000). Total bacterial counts from planted soils were considered rhizospheric.

All data were subjected to one-way analysis of variance (ANOVA) and then to Tukey's Pairwise Comparison test; F-values were obtained when significant. The germination rate data were analyzed using pairwise difference of means with regard to the number of seeds germinated on the $7^{\text {th }}, 14^{\text {th }}$ and $21^{\text {st }}$ day, at different diesel concentrations. CFU's were compared for diesel concentrations and planted and unplanted treatments. Plant height and dry biomass were subjected to regression analysis. All tests were performed at $5 \%$ using OriginPro 8 software tool (OriginLab, 2008) on a Windows-based system used for all statistical analyses.

\section{RESULTS AND DISCUSSION}

\section{Germination}

The presence of diesel in soil had no significant detrimental effect on Brachiaria brizantha seed germination after 7,14 and 21 days (Table 2), suggesting its tolerance and potential for phytoremediation of diesel-contaminated surface soils. Nonetheless, seeds of Brachiaria decumbens were significantly affected $(\mathrm{p}<0.05)$ by the presence of diesel when compared to uncontaminated soils. The reduction in germination was pronounced at high diesel concentrations ( 5 and $10 \mathrm{~g} \mathrm{~kg}^{-1}$ ) on the $7^{\text {th }}$ and $14^{\text {th }}$ day. These results agree with previous studies, where it was shown that diesel-tolerance was speciesspecific and a differentiated sensitivity to diesel fuel of members of the same plant family (Adam \& Duncan, 2002). The same was observed in this study, where $B$. decumbens was less tolerant to diesel than B. brizantha.

The number of germinated seeds of Paspalum notatum differed significantly in all treatments after 14 and 21 days (Table 2). Tukey's test showed a significant reduction in the number of germinated seeds at a diesel concentration of $10 \mathrm{~g} \mathrm{~kg}^{-1}$. Thus, the presence of diesel fuel can inhibit the germination of $P$. notatum seeds. Negative effects of diesel on seed germination were also observed by Siddiqui \& Adams (2002), who demonstrated that germination of perennial ryegrass was inhibited for 2 to 4 weeks in diesel-contaminated soils with and without $\mathrm{N}$ and $\mathrm{P}$.

Germination rates for uncontaminated soils differed between grass species tested in this study (Table 2). It is known that B. brizantha has a pronounced dormancy mechanism due to the seed coat structure (Meschede et al., 2004). Moreover, seedling emergence after seed dormancy is variable for most forage grasses, which means that emergence can be irregular as a result of embryo dormancy, the physiological nature or the presence of a seed coat (Previero et al., 1998; Vieira et al., 1998). This could explain the low germination rates observed in the first week of the experiment.

The number of germinated seeds differed significantly between all species after 21 days (Table 2). Germination of $B$. decumbens and $P$. notatum was lower in contaminated soils up to the $7^{\text {th }}$ day of experiment. After three weeks of growth, the germination rate was below $40 \%$, compared to

Table 2. Cumulative germination of Brachiaria brizantha, Brachiaria decumbens and Paspalum notatum in diesel-contaminated soils $\left(0,2.5,5\right.$ and $\left.10 \mathrm{~g} \mathrm{~kg}^{-1}\right)$ measured 7,14 and 21 days after planting

\begin{tabular}{|c|c|c|c|c|c|c|c|c|c|}
\hline \multirow{2}{*}{ Diesel } & \multicolumn{3}{|c|}{ Brachiaria brizantha } & \multicolumn{3}{|c|}{ Brachiaria decumbens } & \multicolumn{3}{|c|}{ Paspalum notatum } \\
\hline & 7 days & 14 days & 21 days & 7 days & 14 days & 21 days & 7 days & 14 days & 21 days \\
\hline $\mathrm{g} \mathrm{kg}^{-1}$ & \multicolumn{9}{|c|}{ Number of germinated seeds } \\
\hline 0 & $0.7 \mathrm{Aa}$ & $3.3 \mathrm{Aa}$ & $4.0 \mathrm{Aa}$ & $13.0 \mathrm{Ab}$ & $17.0 \mathrm{Ab}$ & $17.3 \mathrm{Aa}$ & $1.3 \mathrm{Aa}$ & $29.7 \mathrm{Ac}$ & $42.0 \mathrm{Ab}$ \\
\hline 2.5 & $2.7 \mathrm{Aa}$ & $6.3 \mathrm{Aa}$ & $6.7 \mathrm{Aa}$ & $5.0 \mathrm{Aa}$ & $10.0 \mathrm{Aa}$ & $11.7 \mathrm{Aa}$ & $1.7 \mathrm{Aa}$ & $23.3 \mathrm{Ab}$ & $43.3 \mathrm{Ab}$ \\
\hline 5 & $1.0 \mathrm{Aa}$ & $6.0 \mathrm{Aa}$ & $6.0 \mathrm{Aa}$ & 1. $3 \mathrm{Ba}$ & 11. $0 \mathrm{Aab}$ & $11.3 \mathrm{Aa}$ & $0.3 \mathrm{Aa}$ & $18.3 \mathrm{Ab}$ & $39.0 \mathrm{Ab}$ \\
\hline 10 & $3.0 \mathrm{Aa}$ & $5.3 \mathrm{Aa}$ & $5.7 \mathrm{Aa}$ & $0.7 \mathrm{Bb}$ & $3.7 \mathrm{Ba}$ & $5.3 \mathrm{Aa}$ & $0.3 \mathrm{Ab}$ & $9.0 \mathrm{Ba}$ & 16. $0 \mathrm{Bb}$ \\
\hline
\end{tabular}

Average values of three replicates followed by different letters within columns (upper-case letters) and rows (lower-case letters) indicate statistical differences (mean comparison between species at the same time period); Tukey at $5 \%$. 


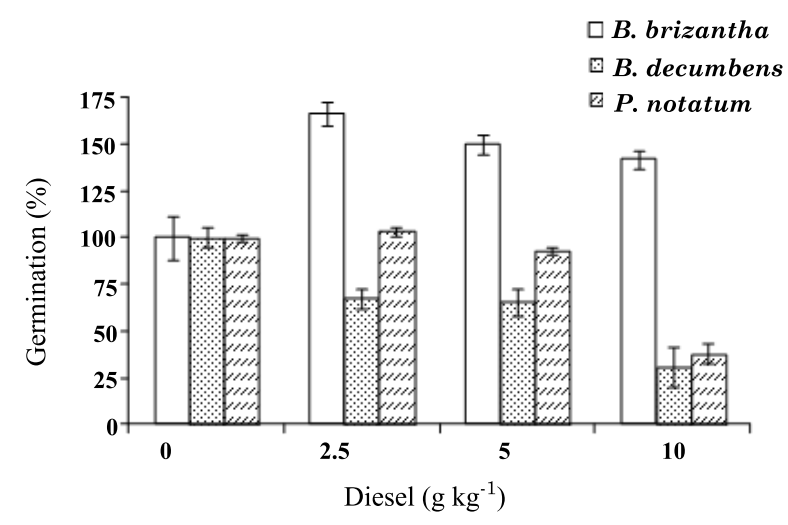

Figure 1. Seed germination of Brachiaria brizantha, Brachiaria decumbens and Paspalum notatum grown on control and diesel-treated soil $(0,2.5,5$ and $10 \mathrm{~g} \mathrm{~kg}^{-1}$ ) after three weeks of growth. Bars represent standard error of triplicates.

plants in uncontaminated soil (Figure 1). Low germination of grass species was reported for dieselcontaminated soils $\left(25 \mathrm{~g} \mathrm{~kg}^{-1}\right)$ after one week of experiment (Adam \& Duncan, 2002). Figure 1 shows the germination percentage ratio at different diesel concentrations in soil normalized to the germination results obtained from in uncontaminated soils (negative controls).

After three weeks of treatment, germination inhibition (62\%) at $10 \mathrm{~g} \mathrm{~kg}^{-1}$ was highest for $P$. notatum. This result was not surprising, since increasing concentrations of diesel-contaminated soils are likely to inhibit the germination of other grass species also, as observed for perennial ryegrass (Lolium perenne L.) (Siddiqui \& Adams, 2002). The inhibition of ryegrass germination was linked to the presence of the highly volatile hydrocarbons in diesel, indicating their influential role in delaying seed emergence and reducing germination rates (Adam \& Duncan, 2002; Siddiqui \& Adams, 2002). This could explain the lower germination rates observed at the beginning of the experiment when most of the volatile hydrocarbons were still trapped in the soil.

\section{Plant biomass}

The increasing diesel concentrations affected plant growth (Figure 2). The shoot height of B. decumbens and $P$. notatum was reduced by 53 and $72 \%$, compared to uncontaminated controls, respectively. A non-linear regression curve model showed a significant reduction of shoot height and growth inhibition of $B$. decumbens $\left(\mathrm{R}^{2}=1\right)$ and $P$. notatum $\left(\mathrm{R}^{2}=0.98\right)$ at all diesel concentrations tested (Figure 2).

Interestingly, B. brizantha showed no significant difference in growth, independently of the diesel concentration (Table 3). This observation indicates $B$. brizantha tolerance to the tested diesel contamination levels. However, the same was not observed for $B$. decumbens plants, which were $50 \%$ shorter when exposed to a diesel concentrations of $10 \mathrm{~g} \mathrm{~kg}^{-1}$ (Table 3). Similarly, there was a statistically significant $(\mathrm{p}<0.05)$ reduction of $47 \%$ in plant height in $P$. notatum at the highest concentration (Table 3 ). For comparison, the development of the leguminous plant Vicia sativa and the grass species Lolium multiflorum were not affected by diesel-contaminated soils (15 $\mathrm{g} \mathrm{kg}^{-1}$ ) after 4 months of treatment (Adam \& Duncan, 2003). The development of the grass species $L$. perenne exposed to a diesel concentrations of $25 \mathrm{~g} \mathrm{~kg}^{-1}$ reduced root and shoot growth significantly, as well as weight (reduction of $57 \%$ ) after 50 days of treatment (Kechavarzi et al., 2007).

Roots of $B$. brizantha did not differ from the uncontaminated soils, with branching that exploited the entire soil volume in the pots. The cumulative shoot (73\%) and root (79 \%) dry matter of B. brizantha reflects the ability of this species to germinate, grow and develop in the presence of diesel at the highest diesel concentration $\left(10 \mathrm{~g} \mathrm{~kg}^{-1}\right)$, compared to the controls (Table 4). Similar findings were reported during the selection of plants for phytoremediation of diesel- and petroleum-contaminated environments using B. brizantha (Tesar et al., 2002; Merkl et al., 2005; Kechavarzi et al., 2007; Peng et al., 2009). Thus, preliminary plant tests are decisive for the success of phytoremediation and can contribute to an appropriate environment restoration in cases of accidental spills on soil surface.

Although not statistically different from the negative controls, the biomass of $P$. notatum was reduced by $59 \%$ at a diesel concentration of $10 \mathrm{~g} \mathrm{~kg}^{-1}$ (Table 4). It should be mentioned that the elevated

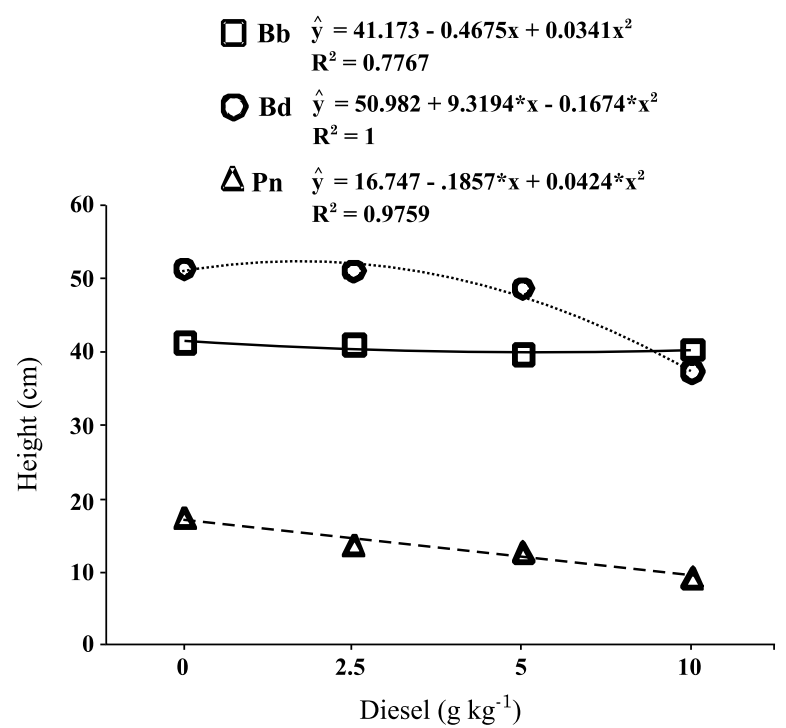

Figure 2. Brachiaria brizantha (Bb), Brachiaria decumbens (Bd) and Paspalum notatum (Pn) height $(\mathrm{cm})$ as a function of diesel fuel levels $(0$, $2.5,5$ and $10 \mathrm{~g} \mathrm{~kg}^{-1}$ ) after 10 weeks of treatment. *: significant at $5 \%$ based on the $F$ test. 
Table 3. Plant height (cm) of Brachiaria brizantha, B. decumbens and Paspalum notatum grown on control and diesel-contaminated soil $\left(0,2.5,5\right.$ and $\left.10 \mathrm{~g} \mathrm{~kg}^{-1}\right)$ after 10 weeks of treatment

\begin{tabular}{|c|c|c|c|c|c|c|c|c|c|}
\hline \multirow{2}{*}{ Diesel } & \multicolumn{9}{|c|}{ Week } \\
\hline & 1 & 2 & 3 & 4 & 5 & 6 & 7 & 8 & 10 \\
\hline \multirow{2}{*}{\multicolumn{10}{|c|}{ Brachiaria hrizantha height (cm) }} \\
\hline & & & & & & & & & Brachiaria brizantha height $(\mathrm{cm})$ \\
\hline 0 & $0.3 \mathrm{~A}$ & $4.0 \mathrm{~A}$ & $6.2 \mathrm{~A}$ & $9.7 \mathrm{~A}$ & $22.7 \mathrm{~A}$ & $24.7 \mathrm{~A}$ & $34.0 \mathrm{~A}$ & $37.0 \mathrm{~A}$ & $41.0 \mathrm{~A}$ \\
\hline 2.5 & $0.3 \mathrm{~A}$ & $2.9 \mathrm{~A}$ & $5.6 \mathrm{~A}$ & $10.3 \mathrm{~A}$ & $22.3 \mathrm{~A}$ & $26.0 \mathrm{~A}$ & $33.7 \mathrm{~A}$ & $36.3 \mathrm{~A}$ & $40.7 \mathrm{~A}$ \\
\hline 5 & $0.4 \mathrm{~A}$ & $3.5 \mathrm{~A}$ & $5.1 \mathrm{~A}$ & $12.0 \mathrm{~A}$ & $25.0 \mathrm{~A}$ & 27. $3 \mathrm{~A}$ & $31.0 \mathrm{~A}$ & $36.3 \mathrm{~A}$ & $39.3 \mathrm{~A}$ \\
\hline 10 & $0.6 \mathrm{~A}$ & $2.6 \mathrm{~A}$ & $3.6 \mathrm{~A}$ & $8.0 \mathrm{~A}$ & $16.5 \mathrm{~A}$ & $21.7 \mathrm{~A}$ & $26.0 \mathrm{~A}$ & $31.3 \mathrm{~A}$ & $40.0 \mathrm{~A}$ \\
\hline \multirow[t]{2}{*}{ CV (\%) } & 34.0 & 19.5 & 21.7 & 16.6 & 16.7 & 9.7 & 11.9 & 7.5 & 1.8 \\
\hline & \multicolumn{9}{|c|}{ Brachiaria decumbens height $(\mathrm{cm})$} \\
\hline 0 & $1.2 \mathrm{~A}$ & $4.2 \mathrm{~A}$ & $7.5 \mathrm{~A}$ & $13.3 \mathrm{~A}$ & $22.0 \mathrm{~A}$ & $29.0 \mathrm{~A}$ & $42.7 \mathrm{~A}$ & $43.7 \mathrm{~A}$ & $51.0 \mathrm{~A}$ \\
\hline 2.5 & $0.8 \mathrm{~A}$ & $3.6 \mathrm{~A}$ & $6.6 \mathrm{~A}$ & $11.5 \mathrm{~A}$ & $26.0 \mathrm{~A}$ & $32.0 \mathrm{~A}$ & $41.0 \mathrm{~A}$ & $38.0 \mathrm{~A}$ & $50.7 \mathrm{~A}$ \\
\hline 5 & $0.7 \mathrm{~A}$ & $2.1 \mathrm{~A}$ & $3.9 \mathrm{~A}$ & $9.6 \mathrm{~B}$ & $22.0 \mathrm{~A}$ & $22.7 \mathrm{~A}$ & $34.7 \mathrm{~A}$ & $40.7 \mathrm{~A}$ & 48. $3 \mathrm{~A}$ \\
\hline 10 & $0.7 \mathrm{~A}$ & $2.5 \mathrm{~A}$ & $2.6 \mathrm{~B}$ & $6.4 \mathrm{C}$ & $10.5 \mathrm{~B}$ & $15.0 \mathrm{~B}$ & $17.7 \mathrm{~B}$ & $24.3 \mathrm{~B}$ & $37.0 \mathrm{~B}$ \\
\hline \multirow[t]{2}{*}{ CV (\%) } & 29.1 & 30.4 & 44.1 & 29.2 & 33.2 & 30.5 & 33.6 & 23.3 & 14.1 \\
\hline & \multicolumn{9}{|c|}{ Paspalum notatum height $(\mathrm{cm})$} \\
\hline 0 & 4. $3 \mathrm{~A}$ & $1.8 \mathrm{~A}$ & $2.3 \mathrm{~A}$ & $2.7 \mathrm{~A}$ & $5.2 \mathrm{~A}$ & $5.4 \mathrm{~A}$ & $9.3 \mathrm{~A}$ & $9.7 \mathrm{~A}$ & $17.0 \mathrm{~A}$ \\
\hline 2.5 & $1.7 \mathrm{~A}$ & $1.8 \mathrm{~A}$ & $2.6 \mathrm{~A}$ & $2.8 \mathrm{~A}$ & $4.8 \mathrm{~A}$ & $5.5 \mathrm{~A}$ & $9.3 \mathrm{~A}$ & $9.3 \mathrm{~A}$ & $13.3 \mathrm{~A}$ \\
\hline 5 & $2.1 \mathrm{~A}$ & $2.0 \mathrm{~A}$ & $2.7 \mathrm{~A}$ & $3.0 \mathrm{~A}$ & $5.5 \mathrm{~A}$ & $6.3 \mathrm{~A}$ & $8.3 \mathrm{~A}$ & $9.3 \mathrm{~A}$ & $12.3 \mathrm{~A}$ \\
\hline 10 & $0.5 \mathrm{~A}$ & $2.2 \mathrm{~A}$ & $1.9 \mathrm{~A}$ & $2.3 \mathrm{~A}$ & $3.7 \mathrm{~A}$ & $3.5 \mathrm{~A}$ & $7.5 \mathrm{~A}$ & $7.7 \mathrm{~A}$ & $9.0 \mathrm{~B}$ \\
\hline $\mathrm{CV}(\%)$ & 74.1 & 10.1 & 14.9 & 11.4 & 16.7 & 23.1 & 10.3 & 10.0 & 25.5 \\
\hline
\end{tabular}

Average values from triplicates followed by different letters within columns indicate statistical differences. Tukey at $5 \%$.

Table 4. Root, shoot and total biomass per plant (average values from triplicates) of Brachiaria brizantha and $P$. notatum grown on control and diesel-treated soil $\left(0,2.5,5\right.$ and $\left.10 \mathrm{~g} \mathrm{~kg}^{-1}\right)$ after 10 weeks of treatment

\begin{tabular}{|c|c|c|c|c|c|c|}
\hline \multirow{3}{*}{ Diesel } & \multicolumn{6}{|c|}{ Dry matter } \\
\hline & \multicolumn{3}{|c|}{ Brachiaria brizantha } & \multicolumn{3}{|c|}{ Paspalum notatum } \\
\hline & Root & Shoot & Total & Root & Shoot & Total \\
\hline \multicolumn{7}{|l|}{$\mathrm{g} \mathrm{kg}^{-1}$} \\
\hline 0 & 1.80 & 2.28 & 4.08 & 0.82 & 0.69 & 1.51 \\
\hline 2.5 & 1.63 & 2.22 & 3.85 & 0.92 & 0.55 & 1.47 \\
\hline 5 & 1.65 & 2.20 & 3.85 & 0.55 & 0.42 & 0.97 \\
\hline 10 & 1.42 & 1.65 & 3.07 & 0.31 & 0.31 & 0.62 \\
\hline CV (\%) & 3.74 & 8.79 & 6. 20 & 61.68 & 60.52 & 60.92 \\
\hline
\end{tabular}

coefficient of variation ( $\mathrm{CV} \%$ ) obtained for this particular experiment may have avoided statistical differences.

B. decumbens showed a significant decrease of root and shoot biomass (dry matter) as a function of diesel concentrations (Figure 3). Compared to control plants, root and shoot dry matter of $B$. decumbens was reduced by 71 and $63 \%$ at the highest diesel level (10 $\left.\mathrm{g} \mathrm{kg}^{-1}\right)$, respectively. B. decumbens biomass was reduced by $66 \%$ when exposed to a diesel concentration of $10 \mathrm{~g} \mathrm{~kg}^{-1}$ after 70 days of treatment. The negative effects of diesel on plant development, especially on biomass, were documented elsewhere. For instance, Kechavarzi et al. (2007) observed an $8 \%$ reduction in shoot biomass of $L$. perenne exposed to $0.025 \mathrm{~g} \mathrm{~kg}^{-1}$ diesel contamination after 52 days of tretament. Similarly, Palmroth et al. (2002) reported a $64 \%$ loss in biomass in grasses exposed to $0.5 \%$ diesel $\left(2.5 \mathrm{~g} \mathrm{~kg}^{-1}\right)$ after 50 days.

\section{Bacteria quantification}

The number of soil bacteria in contaminated, unplanted soil was four to seven times higher $\left(10 \mathrm{~g} \mathrm{~kg}^{-1}\right)$ than in uncontaminated, unplanted soil (controls) (Figure 4). A similar increase in microbial population was observed for unplanted soils contaminated with $10 \mathrm{~g} \mathrm{~kg}^{-1}$ diesel after 98 days of treatment (Jones et al., 2004). Bacterial concentrations in unplanted soil increased with the increasing diesel concentrations, suggesting that diesel was growth limiting rather than inhibiting and served as carbon source for bacterial growth at the concentrations tested (Figure 4). Several studies have reported the increased microbial biomass in hydrocarbon contaminated soils 


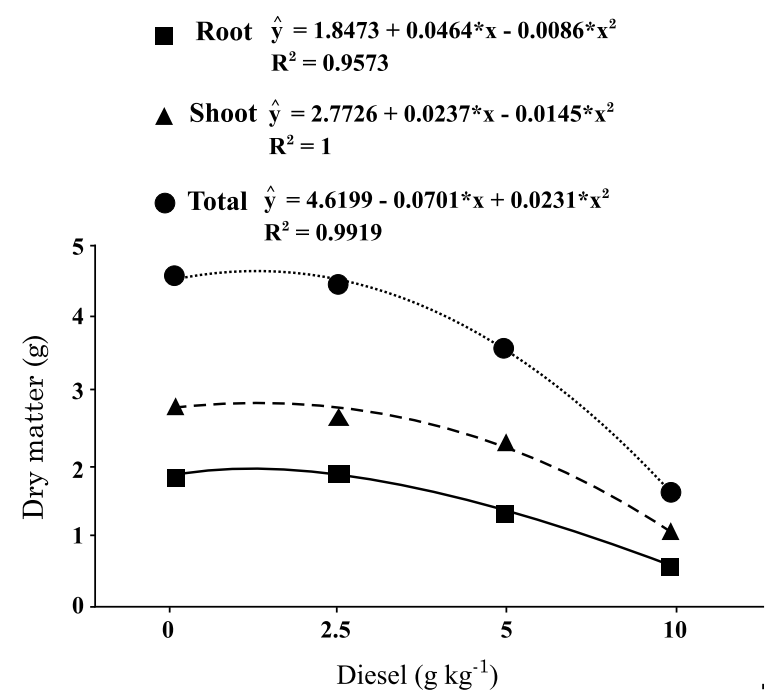

Figure 3. Root, shoot and total biomass of Brachiaria decumbens grown on control and diesel-treated soil after 10 weeks of analysis. *: significant at $5 \%$ by the F test.

(Chaineau et al., 1995, 1996; Kirk et al., 2005; Gaskin \& Benthan, 2010).

After four weeks of treatment, bacterial numbers increased proportionally to diesel concentrations in $B$. decumbens and $P$. notatum rhizospheric soil (Figure 4a). The highest number of CFUs was observed in B. decumbens soil at $10 \mathrm{~g} \mathrm{~kg}^{-1}$, followed by $P$. notatum and $B$. brizantha (Figure $4 a$ ). The number of CFUs in $B$. decumbens rhizospheric soil was significantly higher at all diesel concentrations tested and after 10 weeks of treatment (Figure $4 \mathrm{~b}$ ). Although a significant reduction of $B$. decumbens root biomass was observed, the bacterial population in its rhizosphere was the largest in this study. The effects of the interactions between rhizosphere exudates on the stimulatory growth of vigorous and specific hydrocarbon-degrading bacteria were not within the scope of this study. However, the implications of the root exudate composition on bacteria diversity and concentration have been discussed elsewhere (Tsai \& Philips, 1991; Da Silva et al., 2006; Leigh et al., 2006; Gaskin \& Benthan, 2010). The low biomass and reduced development of $B$. decumbens observed when exposed to diesel suggests that diesel removal from soil is most likely associated with the activity of hydrocarbon-degrading bacteria living in the rhizosphere surroundings rather than with the plant tissues or evapotranspiration. In the $10^{\text {th }}$ week, bacterial counts decreased (Figure 4b), probably due to the exacerbation of diesel hydrocarbons as substrate to support biomass (Tejada \& Gonzalez, 2007; Tejada et al., 2008; Serrano et al., 2009).

The effect of the rhizosphere (R/S) on bacteria populations (Katznelson, 1946) was evaluated in the $4^{\text {th }}$ and $10^{\text {th }}$ week of treatment (Figure 5a). Bacteria concentrations were higher in all soils with plants compared to unplanted soils, demonstrating the beneficial effects of rhizosphere-bacteria interactions (Crawford \& Wilkens, 1998; Roelofs et al., 2001). Because root exudates contain compounds structurally similar to various petroleum hydrocarbons (Toyama et al., 2001) the growth of specific hydrocarbon-degrading bacteria can be stimulated. Nonetheless, the stimulatory effects of the rhizosphere of these grasses on specific bacteria carrying hydrocarbon catabolic genes was not evaluated and future studies will have to confirm our findings. After 10 weeks of treatment, the effects of rhizosphere on bacteria concentration (R/S) were mostly negligible (Figure 5b). This could be attributed to the unavailability of hydrocarbons (removed by degradation or volatilization losses after 10 weeks of treatment) as carbon source to support bacterial growth.

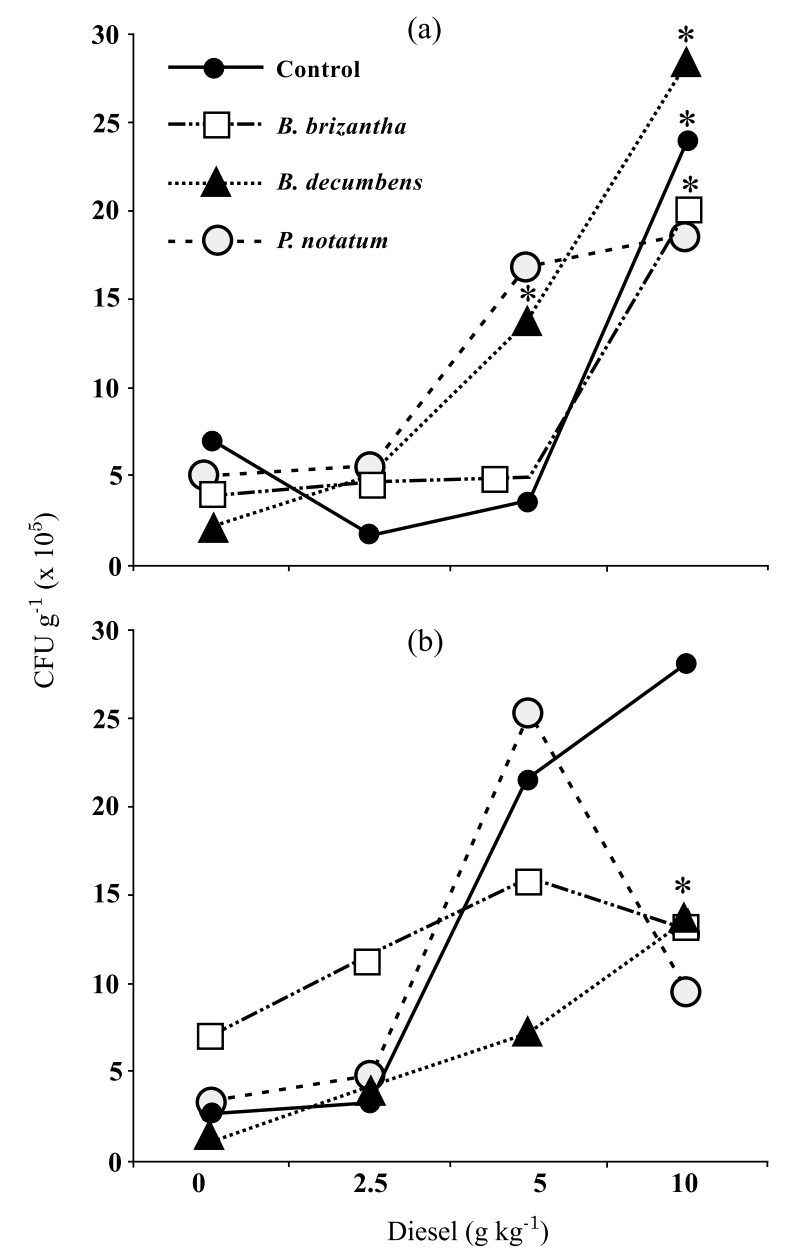

Figure 4. Number of bacterial colony-forming units (CFU) per gram of soil contaminated with different diesel concentrations, after 4 (a) and 10 weeks (b) of treatment. *: significant at $5 \%$, by Tukey's LSD test. 


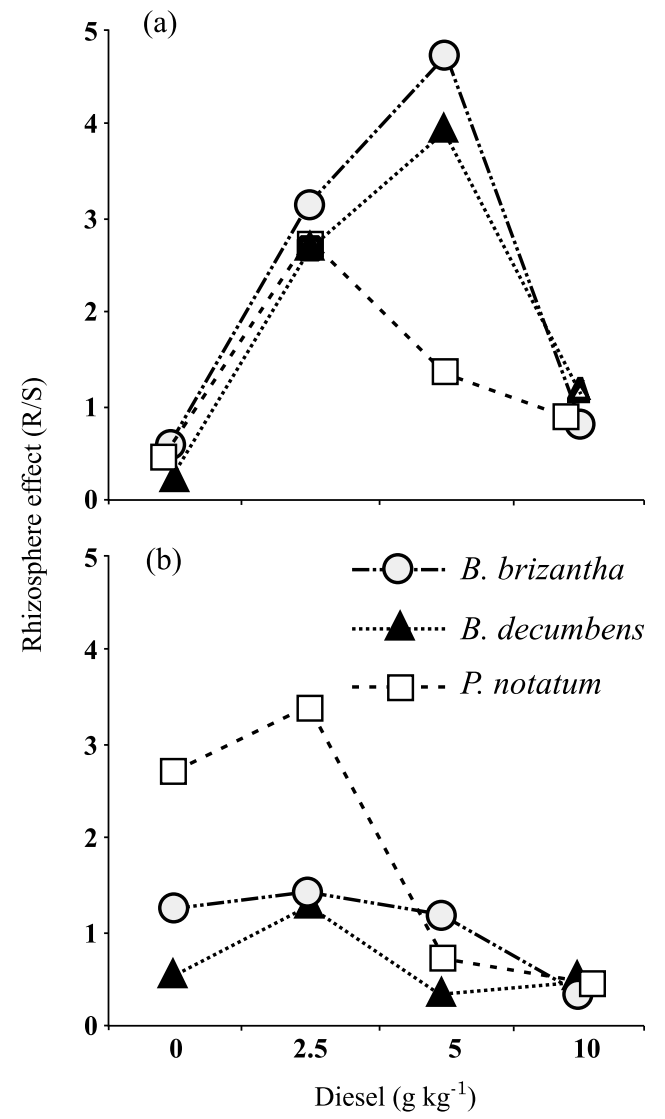

Figure 5. Effect of plant rhizosphere of $B$. brizantha, $B$. decumbens and $P$. notatum on bacterial numbers in soil contaminated with different diesel concentrations and after 4 (a) and 10 weeks (b) of treatment. The number of bacteria in soil with plants $(R)$ divided by the number of bacteria in soil without plants (S) was used to estimate the rhizosphere effects.

\section{CONCLUSIONS}

1. Plant germination, height and biomass showed that $B$. brizantha was not inhibited by the contamination of diesel in the soil. This species was notably tolerant to the diesel concentrations tested, demonstrating its potential to effectively remediate the contaminated soil surface of diesel spills.

2. Bacterial concentrations increased with the increasing diesel concentrations diesel thus supporting the understanding that diesel served as carbon-source that supported plant growth.

3. The increase in bacterial population correlated with the presence of grasses indicating that rhizosphere stimulates bacterial growth and has the potential to promote the growth of specific hydrocarbon-degrading bacteria, which ultimately enhances hydrocarbon removal.

\section{ACKNOWLEDGEMENTS}

The authors would like to thank CAPES (Programa Nacional de Pós-Doutorado - PNPD) for a scholarship as well as Márcio Luís Busi da Silva, $\mathrm{Ph} . D$. from EMBRAPA, for his valuable contributions to this research.

\section{LITERATURE CITED}

ADAM, G. \& DUNCAN, H. Influence of diesel fuel on seed germination. Environ. Pollut., 120:363-370, 2002.

ADAM, G. \& DUNCAN, H. The effect of diesel fuel on common vetch (Vicia sativa L.) plants. Environ. Geochem. Health, 25:123-130, 2003.

ANDERSON, T.A.; GUTHRIE, E.A. \& WALTON, B.T. Bioremediation in the rhizosphere: Plant roots and associated microbes clean contaminated soil. Environ. Sci. Technol., 27:2630-2636, 1993.

BANKS, M.K.; GOVINDARAJU, R.S.; SCHWAB, A.P.; KULAKOW, P. \& FINN, J. In: FIORENZA, S.; OUBRE, C.L. \& WARD, C.H., eds. Phytoremediation of hydrocarboncontaminated soil. Boca Raton, Lewis Publishers, 2000. p.3-88.

BRAGA, J.M. Aspectos qualitativos do calcário. Inf. Agropec., 15:170, 5-11, 1991.

BURKEN, J.G. \& SCHNOOR, J.L. Distribution and volatilization of organic contaminants following uptake by hybrid poplar trees. Intern. J. Phytorem., 1:139-152, 1999.

CHAINEAU, C.H.; MOREL, J.L. \& OUDOT, J. Microbial degradation in soil microcosms of fuel oil hydrocarbons from drilling cuttings. Environ. Sci. Technol., 29: 16151626, 1995.

CHAINEAU, C.H.; MOREL, J.L. \& OUDOT, J. Land treatment of oil-based drill cuttings in an agricultural soil. J. Environ. Qual., 24:858-870, 1996.

CHAUDHRY, Q.; BLOM-ZANDSTRA, M.; GUPTA, S. \& JONER, E.J. Utilizing the synergy between plants and rhizosphere microorganisms to enhance breakdown of organic pollutants in the environment. Environ. Sci. Pollut. Res., 12:34-48, 2005.

CHILCOTT, R.P. Compendium of chemical hazards: Diesel. Version 2. 2011. 37p. Available at: <http:// www.hpa.org.uk/web/HPAwebFile/HPAweb_C/ 1194947407378>. Access date: Aug. 25, 2011.

COLEMAN, J.O.; BLAKE-KALFF, M.M. \& DAVIES, T.G. Detoxification of xenobiotics by plants: Chemical modifications and vacuolar compartmentation. Trends Plant. Sci., 2:144-151, 1997.

CORSEUIL, H.X.; MONIER, A.L.; FERNANDES, M.; SCHNEIDER, M.R.; NUNES, C.C.; ROSARIO, M. \& ALVAREZ, P.J.J. BTEX Plume dynamics following an ethanol blend release: Geochemical footprint and thermodynamic constraints on natural attenuation. Environ. Sci. Technol., 45:3422-3429, 2011. 
CRAWFORD, S. \& WILKENS, S. Effect of aluminium on root elongation in two Australian perennial grasses. Austr. J. Plant Physiol, 25:165-171, 1998.

CUNNINGHAM, S.D.; ANDERSON, T.A.; SCHWAB, P. \& HSU, F.C. Phytoremediation of soils contaminated with organic pollutants. Adv. Agron., 56:55-114, 1996.

DA SILVA, M.L.B.; KAMATH, R. \& ALVAREZ, P.J.J. Effect of stimulated rhizodeposition on the relative abundance of polynuclear aromatic hydrocarbon catabolic genes in a contaminated soil. Environ. Toxicol. Chem., 25:386-391, 2006.

EMPRESA BRASILEIRA DE PESQUISA AGROPECUARIA EMBRAPA. Manual e métodos de análise de solo. 2.ed. Rio de Janeiro, 1997. 212p.

ENVIRONMENTAL PROTECTION AGENCY - EPA. Landfarming In: How to evaluate alternative cleanup technologies for underground storage tank sites: A guide for corrective action Plan reviews. 1994. (EPA 510-B-94003 and EPA 510-B-95-007)

GASKIN, S.E. \& BENTHAM, R.H. Rhizoremediation of hydrocarbon contaminated soil using Australian native grasses. Sci. Total Environ., 408:3683-3688, 2010.

JONES, R.K.; SUN, W.H.; TANG, C.S. \& ROBERT, F.M Phytoremediation of petroleum hydrocarbons in tropical coastal soils II. Microbial response to plant roots and contaminant. Environ. Sci. Pollut. Res., 11:340-346, 2004.

KAMATH, R.; RENTZ, J.A.; SCHNOOR, J.L. \& ALVAREZ, P.J.J. Phytoremediation of hydrocarbon-contaminated soils: Principles and applications. In: VAZQUEZ-DUHALT, R. \& QUINTERO-RAMIREZ, R., eds. Studies in surface science and catalysis. Amsterdam, Elsevier, 2004. p.447. 478.

KATZNELSON, H. The rhizosphere effect of mangels on certain groups of soil microorganisms. Soil Sci., 62:343$54,1946$.

KECHAVARZI, C.; PETTERSSON, K.; LEEDS-HARRISON, P.; RITCHIE, L. \& LEDIN, S. Root establishment of perennial ryegrass (L. perenne) in diesel contaminated subsurface soil layers Environ. Pollut., 145:68-74, 2007.

KIM, J.; KANG, S.H.; MIN, K.A.; CHO, K.S. \& LEE, I.S. Rhizosphere microbial activity during phytoremediation of diesel-contaminated soil. J. Environ. Sci. Health A. Tox. Hazard Subst. Environ. Eng., 41:2503-2516, 2006.

KIRK, J.L.; KLIRONOMOS, J.N.; LEE, H. \& TREVORSA, J.T. The effects of perennial ryegrass and alfalfa on microbial abundance and diversity in petroleum contaminated soil. Environ. Pollut., 133:455-465, 2005.

KOMIVES, T. \& GULLNER, G.D. Dendroremediation: The use of trees in cleaning up polluted soils. In: MACKOVA, M.; DOWLING, D.N. \& MACEK, T., eds. Phytoremediation and Rhizoremediation. Dordrecht, Springer Publisher, 2006. p.23-32.

KUIPER, I.; LAGENDIJK, E.L.; BLOEMBERG, G.V. \& LUGTENBERG, B.J.J. Rhizoremediation: A beneficial plant-microbe interaction. Molec. Plant Microbe Interact., 17:6-15, 2004.
LEIGH, M.B. Methods for rhizoremediation research: Approaches to experimental design and microbial analysis. In: MACKOVA, M.; DOWLING, D.N. \& MACEK, T., eds. Phytoremediation and Rhizoremediation. Dordrecht, Springer Publisher, 2006. p.33-56.

MERKL N.; SCHULTZE-KRAFT, R. \& INFANTE, C. Assessment of tropical grasses and legumes for phytoremediation of petroleum-contaminated soils. Water Air Soil Pollut., 165:195-209, 2005.

MESCHEDE, D.P.; SALES, J.G.C.; BRACCINI, A.L.; SCAPIM, C.A. \& SCHUAB, S.R. Tratamentos para superação da dormência das sementes de capim-braquiária cultivar Marandu. R. Bras. Sementes, 26:76-81, 2004.

MEZZARI, M.P.; van AKEN, B.; YOON, J.M.; JUST, C.L. \& SCHNOOR, J.L. Mathematical modeling of RDX and HMX metabolism in poplar (Populus deltoides $\times$ Populus nigra, DN34) tissue culture. Int. J. Phytorem., 6:323-345, 2004.

MEZZARI, M.P.; WALTERS, K.; JELÍNKOVA, M.; SHIH, M.C.; JUST, C.L. \& SCHNOOR, J.L. Gene expression and microscopic analysis of arabidopsis exposed to chloroacetanilide herbicides and explosive compounds. A phytoremediation approach. Plant Physiol., 138:858-869, 2005.

PALMROTH, M.R.T.; PICHTEL, J. \& PUHKKA, J. Phytoremediation of subarctic soil contaminated with diesel fuel. Biores. Technol., 84:221-228, 2002.

PENG, S.; ZHOU, Q.; CAI, Z. \& ZHANG, Z. Phytoremediation of petroleum contaminated soils by Mirabilis Jalapa L. in a greenhouse plot experiment. J. Hazard. Mat., 168:1490-1496, 2009

PICHTEL, J. \& LISKANEN, P. Degradation of diesel fuel in rhizosphere soil. Environ. Eng. Sci., 18:145-157, 2001.

POHL, H.R.; HANSEN, C.-H.; SELENE \& CHOU, J. Health guidance values for chemical mixtures: current practice and future directions. Regul. Toxicol. Pharmacol., 26:322$329,1997$.

PREVIERO, C.A.; GROTH, D. \& RAZERA, L.F. Dormência de sementes de Brachiaria brizantha (Hochst. ex A.Rich) Stapf armazenadas com diferentes teores de água em dois tipos de embalagens. R. Bras. Sementes, 20:392-397, 1998.

RAIJ, B.van. \& BATAGLIA, O.C. Análises de laboratório. In: OLIVEIRA, A.J.; GARRIDO, W.E.; ARAÚJO, J.D. \& LOURENÇO, S., cood. Métodos de pesquisa em fertilidade do solo. Brasília, Embrapa-SEA, 1991. p.81-101. (EmbrapaSEA. Documentos, 3).

ROELOFS, R.; RENGEL, Z.; CAWTHRAY, G.; DIXON, K. \& LAMBERS, H. Exudation of carboxylates in Australian Proteaceae: Chemical composition. Plant Cell Environ., 24:891-903, 2001.

SANDERMAN, J.H. Higher plant metabolism of xenobiotics: The "green liver" concept. Pharmacogenetics, 4:225-241, 1994. 
SCHNOOR, J.L.; LICHT, L.A.; MCCUTCHEON, S.C.; WOLFE, N.L. \& CARREIRA, L.H. Phytoremediation of organic and nutrient contaminants. Environ. Sci. Technol., 29:318A-323A, 1995.

SCHNOOR, J.L. Environmental modeling. New York, John Wiley \& Sons, 1996. 682p.

SERRANO, A.; TEJADA, M.; GALLEGO, M. \& GONZALEZ, J.L. Evaluation of soil biological activity after a diesel fuel spill. Sci. Total Environ., 407:4056-4061, 2009.

SIDDIQUI, S. \& ADAMS, W.A. The fate of diesel hydrocarbons in soils and their effect on the germination of perennial ryegrass. Environ. Toxicol., 17:49-62, 2002.

SOCIEDADE BRASILEIRA DE CIÊNCIA DO SOLO - SBCS. Manual de adubação e de calagem para os Estados do Rio Grande do Sul e Santa Catarina. 10.ed. Porto Alegre, 2004. 400p.

TEJADA, M. \& GONZALEZ, J.L. Application of different organic wastes on soil properties and wheat yield. Agron. J., 99:1597-1606, 2007.

TEJADA, M.; GONZALEZ, J.L.; HERNANDEZ, M.T. \& GARCIA, C. Application of different organic amendments in a gasoline contaminated soil: Effect on soil microbial properties. Biores. Technol., 99:2872-2880, 2008.
TESAR, M.; REICHENAUER, T.G. \& SESSITSCH, A. Bacterial rhizosphere populations of black poplar and herbal plants to be used for phytoremediation of diesel fuel. Soil Biol. Biochem., 34:1883-1892, 2002.

TOYAMA, T.; FURUKAWA, T.; MAEDA, M.; INOUE, D.; SEI, K.; MORI, K.; KIKUCHI, S. \& IKE, M. Accelerated biodegradation of pyrene and benzo[a]pyrene in the Phragmites australis rhizosphere by bacteria-root exudate interactions. Water Res., 45:1629-1638, 2001.

TSAI, S.M. \& PHILLIPS, D.A. Flavonoids released naturally from alfalfa promote development of symbiotic Glomus spores in vitro. Appl. Environ. Microbiol., 57:1485-1488, 1991.

VIEIRA, H.D.; SILVA, R.F. \& BARROS, R.S. Efeito de substâncias reguladoras de crescimento sobre a germinação de sementes de braquiarão cv. Marandu. R. Bras. Fisiol. Veg., 19:143-148, 1998. 